\title{
Production performance, nutrient digestibility, and milk fatty acid profile of lactating dairy cows fed corn silage- or sorghum silage-based diets with and without xylanase supplementation
}

\author{
Y. Yang, ${ }^{1}$ G. Ferreira, ${ }^{1 *}$ B. A. Corl, ${ }^{1}$ and B. T. Campbell ${ }^{2}$ \\ ${ }^{1}$ Department of Dairy Science, Virginia Tech, Blacksburg 24060 \\ ${ }^{2}$ DSM Nutritional Products, Parsippany, NJ 07054
}

\section{ABSTRACT}

The objective of this study was to evaluate the effects of supplementing xylanase on production performance, nutrient digestibility, and milk fatty acid profile in high-producing dairy cows consuming corn silage- or sorghum silage-based diets. Conventional corn $(80,000$ seeds/ha) and brown midrib forage sorghum $(250,000$ seeds/ha) were planted, harvested [34 and $32 \%$ of dry matter (DM), respectively], and ensiled for more than 10 mo. Four primiparous and 20 multiparous Holstein cows were randomly assigned to 1 of 4 diets in a replicated $4 \times 4$ Latin square design with a $2 \times 2$ factorial arrangement of treatments and 19-d periods. Treatment diets consisted of (1) corn silage-based diet without xylanase, (2) corn silage-based diet with xylanase, (3) sorghum silage-based diet without xylanase, and (4) sorghum silage-based diet with xylanase. The xylanase product was supplemented at a rate of $1.5 \mathrm{~g}$ of product $/ \mathrm{kg}$ of total DM. Corn silage had higher concentrations of starch (31.2 vs. $29.2 \%)$, slightly higher concentrations of crude protein (7.1 vs. $6.8 \%$ ) and fat (3.7 vs. $3.2 \%$ ), and lower concentrations of neutral detergent fiber (36.4 vs. $49.0 \%$ ) and lignin (2.1 vs. $5.7 \%$ ) than sorghum silage. Xylanase supplementation did not affect DM intake, milk yield, milk fat percentage and yield, milk protein percentage and yield, lactose percentage and yield, and 3.5\% fat-corrected milk yield. Cows consuming corn silage-based diets consumed $13 \%$ more DM (28.8 vs. $25.5 \mathrm{~kg} / \mathrm{d})$ and produced $5 \%$ more milk (51.6 vs. $48.9 \mathrm{~kg} / \mathrm{d}$ ) than cows consuming sorghum silage-based diets. Milk from cows consuming sorghum silage-based diets had 16\% greater fat concentrations (3.84 and $3.30 \%$ ) than milk from cows consuming corn silage-based diets. This resulted in $8 \%$ greater fat

Received October 5, 2018.

Accepted November 27, 2018.

*Corresponding author: gonf@vt.edu yields (1.81 vs. $1.68 \mathrm{~kg} / \mathrm{d})$. Silage type did not affect milk protein and lactose concentrations. Xylanase supplementation did not affect nutrient digestibility. Cows consuming corn silage-based diets showed greater DM (77.3 vs. $73.5 \%$ ), crude protein (78.0 vs. 72.4 ), and starch (99.2 vs. 96.5\%) digestibilities than cows consuming sorghum silage-based diets. In conclusion, xylanase supplementation did not improve production performance when high-producing dairy cows were fed corn silage- or sorghum silage-based diets. In addition, production performance can be sustained by feeding sorghum silage in replacement of corn silage.

Key words: xylanase, corn silage, sorghum silage, grass hay, drought

\section{INTRODUCTION}

According to the US Department of Agriculture, the drought of spring and summer 2012 will be remembered as one of the worst agricultural calamities in the nation (USDA, 2013). The effects of a major drought are numerous and include shortage of forage stocks and increased forage and grain prices, among others. From a financial perspective, these 2 effects can reduce cash flows at the dairy farm. From a nutritional perspective, finding nutritional strategies that sustain production and revenues while maintaining cows' health is paramount when facing a drought scenario.

Due to its greater drought tolerance, water use efficiency, and transpiration and photosynthetic rates under drought conditions (Hasan et al., 2017; Roby et al., 2017), sorghum (Sorghum bicolor L. Moench) has been proposed as a resilient alternative to corn (Zea mays) under drought scenarios (Brown and Funk, 2008; Roby et al., 2017) for producing silage for feeding dairy cows. Different studies (Oliver et al., 2004; Bernard and Tao, 2015; Cattani et al., 2017) reported similar milk yields and DMI when corn silage was completely replaced by brown midrib (BMR) sorghum silage in diets for lactating dairy cows. Based on these studies, feeding BMR sorghum silage is becoming a suitable alternative 
to feeding corn silage to lactating dairy cows, especially in scenarios of drought stress occurrence.

In some areas of the southeastern United States, such as Virginia, good-quality legume hay can be very scarce. Therefore, unless expensive legume hay is purchased from other regions, dairy farmers from this region may have no alternative other than feeding poor-quality mixed-grass hay to dairy cows. Feeding exogenous fibrolytic enzymes (EFE) to increase fiber digestibility could be a nutritional strategy to maximize feed efficiency and sustain production performance when feeding poor-quality mixed-grass hay. Xylanase is a fibrolytic enzyme that cleaves the $\beta$-1,4-linked backbone of arabinoxylans, a major component of cell walls in grasses (Åman, 1993; Collins et al., 2005). For nonruminants, xylanase supplementation is used to enhance feed values of diets containing barley, oats, or wheat grains (Wang and McAllister, 2002). For ruminants, studies have shown increased NDF digestibility (Arriola et al., 2011) and milk yield (Arriola et al., 2017) when adding EFE to diets of lactating dairy cows.

In this study, we aimed to evaluate different nutritional strategies to overcome the effects of drought stress scenarios (i.e., limited silage and hay availability due to reduced forage yields, limited availability of good-quality hay due to unaffordable prices, or their combination). We hypothesized that adding an EFE to diets containing poor-quality mixed-grass hay increases fiber digestibility and production performance in lactating dairy cows. Therefore, the objective of this study was to evaluate the effects of supplementing xylanase on production performance, nutrient digestibility, and milk fatty acid profile in high-producing dairy cows consuming low-forage diets. We tested these effects when cows consumed corn silage- or sorghum silagebased diets.

\section{MATERIALS AND METHODS}

\section{Silages}

Corn and sorghum crops were grown at the College Farm Operation of Virginia Tech (Blacksburg, VA). A commercial conventional corn (TMF2L825; Mycogen Seeds, Indianapolis, IN) was planted on May 8, 2016, at a seeding rate of 80,000 seeds/ha using a narrow-row (38 $\mathrm{cm}$ ) corn planter (model 1785; John Deere, Moline, IL). The corn crop was cut and chopped on September 10, 2016, with a self-propelled forage chopper (model 7400; John Deere) when it reached a DM concentration between 33 and $35 \%$. The theoretical length of cut was set at $19 \mathrm{~mm}$, and the gap between kernel processing rolls was set at $2 \mathrm{~mm}$. The chopped material was ensiled in 3-m-diameter polyethylene bags (Plastar San Luis S.A., Tilisarao, Argentina). In addition, a commercial forage sorghum (SS 2010 SAF, BMR-6; Southern States Cooperative, Richmond, VA) was planted on June 9, 2016, at a seeding rate of 250,000 seeds/ha using the same corn planter described above. The sorghum crop was cut and chopped on October 14, 2016, once it reached a DM concentration between 31 and $33 \%$. For this, the same self-propelled forage chopper described above was used. The theoretical length of cut was set at $19 \mathrm{~mm}$, and the gap between kernel processing rolls was set at 2 $\mathrm{mm}$. The chopped material was ensiled in 3-m-diameter polyethylene bags (Plastar San Luis S.A.). Both silos were kept sealed until the beginning of the feeding trial, which started on October 24, 2017.

\section{Animals, Housing, and Diets}

All procedures involving animals were approved by the Institutional Animal Care and Use Committee of Virginia Tech. Four primiparous $(581 \pm 47 \mathrm{~kg}$ of BW and $47 \pm 14$ DIM at the beginning of the experiment) and 20 multiparous $(707 \pm 67 \mathrm{~kg}$ of $\mathrm{BW}$ and $51 \pm 14$ DIM at the beginning of the experiment) Holstein cows were randomly assigned to 1 of 4 diets (Table 1 ) in a replicated $4 \times 4$ Latin square design with a $2 \times 2$ factorial arrangement of treatments and 19-d periods. Cows were assigned to squares based on parity (1,2, and $\geq 3$ ) and milk production (10-d pretrial period), housed in a 24-stall pen within a freestall barn, and fed once daily $(1100 \mathrm{~h})$ using a Calan gate system (American Calan Inc., Northwood, NH). Cows were trained for $2 \mathrm{wk}$ before the beginning of the experiment to locate their assigned doors.

Diets were formulated to contain (DM basis) about $32 \%$ corn or sorghum silage, $8 \%$ grass hay, and $60 \%$ pelleted concentrates, which were prepared at a commercial feed mill (Big Spring Mill Inc., Elliston, VA). Treatments consisted of the following: (1) corn silagebased diet without xylanase, (2) corn silage-based diet with xylanase, (3) sorghum silage-based diet without xylanase, and (4) sorghum silage-based diet with xylanase. Following the manufacturer's recommendations, the xylanase product (Ronozyme WX CT; DSM Nutritional Products, Parsippany, NJ) was supplemented at a rate of $1.5 \mathrm{~g}$ of product $/ \mathrm{kg}$ of total DM. This enzyme is an endo-1,4- $\beta$-xylanase from Aspergillus oryzae with no cellulosic or proteolytic activities (Rychen et al., 2017) and maximum activity around $\mathrm{pH} 5$. The enzyme product is a coated thermotolerant formulation that ensures a minimum activity of xylanase of 1,000 fungal xylanase units/g (Rychen et al., 2017). Based on its thermostability, the enzyme was incorporated into the 
concentrate mix before pelleting. All diets were formulated to meet the requirements (NRC, 2001) of a $630-\mathrm{kg}$ lactating dairy cow producing $42 \mathrm{~kg}$ of milk/d.

Concentrate pellets were mixed with either corn or sorghum silage and chopped grass hay (Table 1) and delivered as a TMR in quantities enough to allow approximately $5 \%$ refusals. Mixing and feeding were performed using a Calan Data Ranger (American Calan Inc.). The amount of feed offered and refused was measured daily. Cows were milked twice daily (0100 and $1300 \mathrm{~h}$ ), and milk weights were automatically recorded at each milking. The averages of daily milk yields and DMI from d 13 to 19 of each period were used for statistical analysis.

\section{Nutrient Digestibility}

Total-tract nutrient digestibility was estimated using lanthanum chloride as an external marker as described in Yang et al. (2017). To obtain a final dietary lanthanum concentration of $40 \mathrm{mg} / \mathrm{kg}$ of DM, $42 \mathrm{~kg}$ of the marker solution $($ density $=1.15 \mathrm{~g} / \mathrm{mL}$; $[\mathrm{La}]=102$ $\mathrm{g} / \mathrm{L}$ ) was sprayed onto $1,750 \mathrm{~kg}$ of soybean meal that was incorporated into the concentrate pellets. Fecal grab samples were collected for each period across 3 consecutive days (starting on d 17) at 6-h intervals, skipping sampling times $2 \mathrm{~h}$ at the end of each day. Lanthanum concentration was determined in TMR and fecal samples by inductively coupled plasma atomic emission spectroscopy. Apparent total-tract DM digestibility and apparent total-tract nutrient digestibility were calculated using Equations 1 and 2, respectively.

Table 1 . Ingredient and chemical composition (\%, DM basis) of $\operatorname{diets}^{1}$

\begin{tabular}{|c|c|c|c|c|}
\hline \multirow[b]{2}{*}{ Item } & \multicolumn{2}{|c|}{ Corn silage } & \multicolumn{2}{|c|}{ Sorghum silage } \\
\hline & NX & $\mathrm{X}$ & NX & $\mathrm{X}$ \\
\hline \multicolumn{5}{|l|}{ Ingredient } \\
\hline Corn silage & 33.5 & 33.4 & - & - \\
\hline Sorghum silage & - & - & 33.5 & 33.4 \\
\hline Grass hay & 8.4 & 8.4 & 8.4 & 8.4 \\
\hline Corn grain & 7.1 & 7.1 & 7.1 & 7.1 \\
\hline Wheat grain & 12.6 & 12.6 & 12.6 & 12.6 \\
\hline Soybean meal & 13.0 & 13.0 & 13.0 & 13.0 \\
\hline Dry distillers grains & 4.2 & 4.2 & 4.2 & 4.2 \\
\hline Wheat middlings & 16.8 & 16.7 & 16.8 & 16.7 \\
\hline Calcium salts of fatty acids ${ }^{2}$ & 1.0 & 1.0 & 1.0 & 1.0 \\
\hline Sodium bicarbonate & 1.1 & 1.1 & 1.1 & 1.1 \\
\hline Salt & 0.5 & 0.5 & 0.5 & 0.5 \\
\hline Magnesium oxide & 0.2 & 0.2 & 0.2 & 0.2 \\
\hline Xylanase $^{3}$ & - & 0.2 & - & 0.2 \\
\hline Trace mineral premix ${ }^{4}$ & 0.4 & 0.4 & 0.4 & 0.4 \\
\hline Vitamins $\mathrm{A}, \mathrm{D}$, and $\mathrm{E}^{5}$ & 0.04 & 0.04 & 0.04 & 0.04 \\
\hline Vitamin $\mathrm{E}^{6}$ & 0.003 & 0.003 & 0.003 & 0.003 \\
\hline Rumensin $90^{7}$ & 0.008 & 0.008 & 0.008 & 0.008 \\
\hline \multicolumn{5}{|l|}{ Nutrient } \\
\hline $\mathrm{OM}$ & 93.5 & 93.3 & 92.5 & 92.2 \\
\hline $\mathrm{CP}$ & 14.9 & 14.9 & 14.8 & 14.8 \\
\hline NDF & 33.6 & 32.3 & 37.3 & 37.0 \\
\hline Forage NDF & 18.1 & 18.1 & 22.3 & 22.3 \\
\hline Starch & 27.9 & 28.1 & 24.6 & 25.9 \\
\hline NFC & 43.2 & 44.0 & 38.6 & 39.5 \\
\hline \multicolumn{5}{|c|}{${ }^{1} \mathrm{NX}=$ no xylanase supplemented; $\mathrm{X}=$ xylanase supplemented. } \\
\hline \multicolumn{5}{|c|}{${ }^{2}$ Virtus Nutrition LLC (Corcoran, CA). } \\
\hline \multicolumn{5}{|c|}{${ }^{3}$ Ronozyme WX (DSM Nutritional Products, Parsippany, NJ). } \\
\hline \multicolumn{5}{|c|}{$\begin{array}{l}{ }^{4} \text { Contained } 22.25 \% \text { calcium, } 7.50 \% \text { magnesium, } 2.75 \% \text { potassium, } 3.90 \% \text { sulfur, } 1.50 \% \text { manganese, } 1.50 \% \text { zinc, } \\
9,500 \mathrm{mg} / \mathrm{kg} \text { iron, } 2,500 \mathrm{mg} / \mathrm{kg} \text { copper, } 200 \mathrm{mg} / \mathrm{kg} \text { iodine, } 200 \mathrm{mg} / \mathrm{kg} \text { cobalt, } 66 \mathrm{mg} / \mathrm{kg} \text { selenium, } 227,273 \mathrm{IU} / \\
\mathrm{kg} \text { vitamin A, } 136,364 \mathrm{IU} / \mathrm{kg} \text { vitamin } \mathrm{D}_{3} \text {, and } 636 \mathrm{IU} / \mathrm{kg} \text { vitamin } \mathrm{E} .\end{array}$} \\
\hline \multicolumn{5}{|c|}{$\begin{array}{l}{ }^{5} \text { Contained } 3,500 \mathrm{IU} / \mathrm{kg} \text { vitamin } \mathrm{A}, 950 \mathrm{IU} / \mathrm{kg} \text { vitamin } \mathrm{D}_{3} \text {, and } 2,000 \mathrm{IU} / \mathrm{g} \text { vitamin } \mathrm{E} \text {. } \\
{ }^{6} \text { Contained } 500 \mathrm{IU} / \mathrm{g} \text { of premix. }\end{array}$} \\
\hline \multicolumn{5}{|c|}{${ }^{6}$ Contained $500 \mathrm{IU} / \mathrm{g}$ of premix. } \\
\hline${ }^{7}$ Contained $200 \mathrm{mg}$ of monensi & ait & In & & \\
\hline
\end{tabular}


Nutrient digestibility $(\%)=$

$100-\frac{\text { dietary }[\mathrm{La}](\mathrm{mg} / \mathrm{g} \text { of } \mathrm{DM})}{\text { fecal }[\mathrm{La}](\mathrm{mg} / \mathrm{g} \text { of } \mathrm{DM})}$

$\times \frac{\text { fecal }[\text { nutrient }](\mathrm{g} / \mathrm{g} \text { of } \mathrm{DM})}{\text { dietary }[\text { nutrient }](\mathrm{g} / \mathrm{g} \text { of } \mathrm{DM})} \times 100$

\section{Sample Collection and Analysis}

Samples of feed ingredients and feed refusals were collected weekly. All samples were dried to constant weight at $55^{\circ} \mathrm{C}$ in a forced-air oven and ground to pass through a 1-mm screen of a Wiley mill (Thomas Scientific, Swedesboro, NJ). Ash concentration was determined after combusting samples in a furnace (Thermolyne 30400, Barnstead International, Dubuque, IA) for $3 \mathrm{~h}$ at $600^{\circ} \mathrm{C}$ (method 942.05; AOAC International, 2016). Crude protein concentration was calculated as percentage $\mathrm{N} \times 6.25$ after combustion analysis (method 990.03; AOAC International, 2016) using a Vario El Cube CN analyzer (Elementar Americas Inc., Mount Laurel, NJ). Ash-free NDF and ADF concentrations were determined using the Ankom200 Fiber Analyzer (Ankom Technology, Macedon, NY). Sodium sulfite and $\alpha$-amylase (Ankom Technology) were included for NDF analysis (Ferreira and Mertens, 2007). Concentrations of $\mathrm{ADF}$ and $\mathrm{ADL}$ were determined sequentially. After determining ADF weights, residues were incubated for $3 \mathrm{~h}$ in $72 \%$ sulfuric acid in a $4-\mathrm{L}$ jar that was placed in a DaisyII Incubator (Ankom Technology). Starch concentration was determined using the acetate buffer method of Hall (2009) with $\alpha$-amylase from Bacillus licheniformis (FAA; Ankom Technology) and amyloglucosidase from Aspergillus niger (E-AMGDF; Megazyme International, Wicklow, Ireland).

Milk samples (a.m. and p.m. milkings) were collected on $\mathrm{d} 15$ and 16 of each period for the determination of milk fat, true protein, lactose, and MUN concentrations with a CombiFoss FT + Fourier transform infrared analyzer (Foss, Hillerød, Denmark) by United DHIA (Radford, VA). An additional milk sample (a.m. and p.m. milkings) was collected on d 16 of each period to determine milk fatty acid composition. Milk fatty acids were extracted and methylated according to the method of Chouinard et al. (1999). Fatty acid methyl esters were analyzed by GC as described by Yang et al. (2017).

\section{Statistical Analysis}

All variables were analyzed using the MIXED procedure of SAS (version 9.4; SAS Institute Inc., Cary, NC).
The statistical model included the effects of square (fixed; $\mathrm{df}=5$ ), treatment (fixed; $\mathrm{df}=3$ ), square $\times$ treatment interaction (fixed; $\mathrm{df}=15$ ), period (random; $\mathrm{df}=3$ ), cow within square (random; $\mathrm{df}=18$ ), and the random residual error $(\mathrm{df}=51)$. Orthogonal contrasts were used to test the main effects of xylanase supplementation and silage type and their interaction. Significant differences between main effects were declared at $P<0.05$, and significant interactions were declared at $P<0.10$. When significant interactions were observed, differences among treatment means were contrasted using the pdiff option of SAS.

\section{RESULTS AND DISCUSSION}

Corn silage had higher concentrations of starch $(31.2$ vs. $29.2 \%)$; slightly higher concentrations of $\mathrm{CP}(7.1$ vs. $6.8 \%$ ) and fatty acids (3.7 vs. $3.2 \%$ ); and lower concentrations of NDF (36.4 vs. 49.0\%), ADF (22.3 vs. $32.7 \%$ ), and ADL (2.1 vs. 5.7\%) than sorghum silage (Table 2). Corn silage contained greater concentrations of PUFA than sorghum silage (53.4 vs. $42.3 \%$ ), whereas sorghum silage contained greater concentrations of SFA (24.8 vs. $19.0 \%$ ) and MUFA (33.0 vs. 27.6\%; Table 2) than corn silage.

Despite having the BMR phenotype, sorghum silage contained a greater concentration of ADL in the NDF fraction than corn silage (11.6 and 5.8\%, respectively). The BMR phenotype has been associated with a reduced lignin concentration compared with the non-BMR phenotypes, and this reduced lignin concentration is attributed to a reduction in the synthesis of monolignols (Sattler et al., 2010), the monomeric units for lignin synthesis. Even though we did not anticipate a greater concentration of ADL in the NDF fraction for sorghum silage than for corn silage, this study is not the first to show such a difference. For instance, Bernard and Tao (2015) reported that the concentration of ADL in the NDF fraction was $8.3 \%$ for non-BMR corn silage and $14.2 \%$ for BMR sorghum silage. In other studies (Grant et al., 1995; Cattani et al., 2017; Harper et al., 2018), however, the difference for ADL concentration in the NDF fraction between non-BMR corn silage and BMR sorghum silage was minimal (i.e., $<2$ percentage units). These observations suggest that, when comparing different species, forages carrying the BMR phenotype do not always result in forages with lower lignin concentrations in the fiber fraction.

The grass hay used in this study contained $10.1 \%$ CP, 70.6\% NDF, 43.5\% ADF, and 4.7\% ADL (Table 2 ). According to its relative feed value of 72 , this grass hay is ranked as 5 on a 1-to- 5 scale, where 1 is excellent quality and 5 is poor quality (Rohweder et al., 
Table 2. Chemical composition (\%, DM basis) and fatty acid profile ( $\%$ of total fatty acids) of forages ${ }^{1}$

\begin{tabular}{lccc}
\hline Item & $\begin{array}{c}\text { Corn } \\
\text { silage }\end{array}$ & $\begin{array}{c}\text { Sorghum } \\
\text { silage }\end{array}$ & $\begin{array}{c}\text { Grass } \\
\text { hay }\end{array}$ \\
\hline DM, \% wet weight & 34.3 & 32.9 & 89.0 \\
OM & 93.5 & 93.3 & 92.5 \\
CP & 7.1 & 6.8 & 10.1 \\
NDF & 36.4 & 49.0 & 70.6 \\
ADF & 22.3 & 37.2 & 43.5 \\
ADL & 2.1 & 5.7 & 4.7 \\
Fatty acids & 3.7 & 3.2 & ND \\
NFC & 46.3 & 34.3 & ND \\
Starch & 31.2 & 29.2 & 2.1 \\
C14:0 & 0.27 & 0.50 & ND \\
C14:1 & 0.02 & 0.01 & ND \\
C16:0 & 14.61 & 17.40 & ND \\
C16:1 & 0.14 & 0.38 & ND \\
C18:0 & 2.34 & 2.30 & ND \\
C18:1 cis-9 $918: 1$ cis-11 & 23.49 & 27.06 & ND \\
C18:2 cis-9, cis-12 & 0.65 & 1.15 & ND \\
C18:3 cis-9,cis-12,cis-15 & 46.24 & 36.98 & ND \\
C20:0 & 6.83 & 4.92 & ND \\
C20:1 cis-11 & 0.58 & 1.48 & ND \\
C20:2 & 0.23 & 0.20 & ND \\
C20:4 & 0.04 & 0.03 & ND \\
C20:3 & 0.04 & 0.03 & ND \\
C20:5 & 0.05 & 0.06 & ND \\
C22:0 & 0.17 & 0.20 & ND \\
C22:1 & 0.49 & 1.06 & ND \\
C22:6 & 0.02 & 0.02 & ND \\
C24:0 $24: 1$ cis-15 & 0.01 & 0.05 & ND \\
Other & 0.67 & 2.01 & ND \\
\hline Val & 0.01 & 0.02 & ND \\
& 3.10 & 4.14 & ND \\
\hline
\end{tabular}

${ }^{1}$ Values represent means of weekly collected samples $(\mathrm{n}=12)$.

${ }^{2} \mathrm{ND}=$ not determined

${ }^{3} \mathrm{NFC}=\mathrm{OM}-\mathrm{CP}-\mathrm{NDF}-$ fatty acids.

1978; Hackmann et al., 2008). The grass hay provided $5.9 \%$ of the dietary NDF and 26.5 to $32.6 \%$ of the total forage NDF (corn silage- and sorghum silage-based diets, respectively). Despite its poor nutritional quality, the inclusion of grass hay was critical for this study to secure enough physically effective fiber (Mertens, 1997), as we formulated the diets to contain low forage- to-concentrate ratios and include wheat as the major grain source (Table 1 ).

Xylanase supplementation did not affect DMI $(P<$ $0.10)$, milk yield $(P<0.77)$, milk fat percentage $(P<$ $0.29)$ and yield $(P<0.71)$, milk protein percentage $(P$ $<0.48)$ and yield $(P<0.43)$, lactose percentage $(P<$ $0.84)$ and yield $(P<0.51)$, or $3.5 \%$ FMC yield $(P<$ 0.84; Table 3). Also, none of the interactions between xylanase supplementation and silage type were significant for any of these variables $(P>0.31$; Table 3$)$. These observations are contrary to our expectations. The variable response of production performance by dairy cows to EFE was recently addressed (Arriola et al., 2017). In their meta-analysis, Arriola et al. (2017) suggested that short-term supplementation during crossover or Latin square designs may impede expressing the benefits of supplementing EFE. The short-term feeding periods of the current study might have been insufficient to express the benefits of supplementing EFE on production performance (Arriola et al., 2017). Other factors, such as enzyme stability within the rumen, substrate to enzyme interaction, fast feed passage rate, or cross-linkages between lignin and arabinoxylans (Wang and McAllister, 2002), may have impeded expressing the benefits of supplementing EFE on production performance.

The interaction between xylanase supplementation and silage type was significant for apparent totaltract DM $(P<0.05), \mathrm{CP}(P<0.08)$, and $\mathrm{NDF}(P$ $<0.06$ ) digestibilities (Table 4 ), and this interaction is linked exclusively to the lower digestibility of the corn silage-based diet with xylanase. For 2 reasons, we consider this interaction a random result rather than an actual response to enzyme supplementation. First, the enzyme affected digestibility in corn silage-based diets and not in sorghum silage-based diets. To the best of our knowledge, there is no biological reason for this selective response. Second, the enzyme Ronozyme WX is an endo-1,4- $\beta$-xylanase from Aspergillus oryzae with

Table 3. Production performance of cows consuming corn silage-based diets or sorghum silage-based diets with and without the addition of xylanase (X and NX, respectively)

\begin{tabular}{|c|c|c|c|c|c|c|c|c|}
\hline Item & \multicolumn{2}{|c|}{ Corn silage } & \multicolumn{2}{|c|}{ Sorghum silage } & SEM & \multicolumn{3}{|c|}{$P$-value } \\
\hline DMI, $\mathrm{kg} / \mathrm{d}$ & 29.3 & 28.3 & 26.2 & 24.7 & 1.08 & 0.01 & 0.10 & 0.75 \\
\hline Milk fat, $\%$ & 3.31 & 3.28 & 3.91 & 3.76 & 0.14 & 0.01 & 0.29 & 0.48 \\
\hline Milk fat yield, $\mathrm{kg} / \mathrm{d}$ & 1.68 & 1.67 & 1.82 & 1.80 & 0.11 & 0.01 & 0.71 & 0.88 \\
\hline Milk protein, $\%$ & 2.88 & 2.93 & 2.88 & 2.89 & 0.07 & 0.60 & 0.48 & 0.55 \\
\hline $3.5 \% \mathrm{FCM}, \mathrm{kg} / \mathrm{d}$ & 49.4 & 49.5 & 50.7 & 50.3 & 2.39 & 0.25 & 0.84 & 0.79 \\
\hline
\end{tabular}


no proteolytic activity (Rychen et al., 2017). Therefore, an effect on protein digestibility would not be expected based on the product formulation.

Cows consuming corn silage-based diets consumed $13 \%$ more DM $(28.8$ vs. $25.5 \mathrm{~kg} / \mathrm{d} ; P<0.01)$ than cows consuming sorghum silage-based diets (Table 3 ). In previous studies where sorghum silage completely replaced corn silage (Grant et al., 1995; Oliver et al., 2004; Bernard and Tao, 2015; Cattani et al., 2017), DMI did not differ between treatments. In the current study, silages were included in the diets at similar rates regardless of their nutrient composition. Because of this, corn silage-based diets contained 4 percentage units less NDF and 2 percentage units more starch than sorghum silage-based diets, whereas in the previous studies the nutritional composition of the diets differed less (Oliver et al., 2004; Bernard and Tao, 2015; Cattani et al., 2017). Therefore, we attribute the greater DMI for cows consuming the corn silage-based diets to the lower NDF and greater starch concentrations of these diets, which may have decreased retention time within the rumen and increased the rate of passage from the rumen. Although not measured in this study, different physical characteristics of the silages could also explain the differences in DMI.

Cows consuming corn silage-based diets produced $5 \%$ more milk (51.6 vs. $48.9 \mathrm{~kg} / \mathrm{d} ; P<0.01$ ) than cows consuming sorghum silage-based diets (Table 3 ). In previous studies where sorghum silage completely replaced corn silage (Grant et al., 1995; Oliver et al., 2004; Bernard and Tao, 2015; Cattani et al., 2017), milk yield did not differ between treatments. This response is likely related to the greater DMI observed for cows consuming corn silage-based diets (Table 3). Milk from cows consuming sorghum silage-based diets had $16 \%$ greater fat concentrations (3.84 and 3.30\%; $P<0.01$ ) than milk from cows consuming corn silage-based diets. This resulted in $8 \%$ greater fat yields (1.81 vs. $1.68 \mathrm{~kg} / \mathrm{d}$; $P<0.01)$ for cows consuming sorghum silage-based diets than for cows consuming corn silage-based diets. Similar to this study, previous studies reported greater concentrations of fat in milk from cows fed sorghum silage-based diets relative to cows fed corn silage-based diets (Bernard and Tao, 2015; Cattani et al., 2017), a difference that ranged from 0.20 to 0.62 percentage units. Silage type did not affect milk protein $(P<0.60)$ and lactose $(P<0.51)$ concentrations; therefore, cows consuming corn silage-based diets produced $9 \%$ more protein and $7 \%$ more lactose than cows consuming sorghum silage-based diets. The production of $3.5 \%$ FCM did not differ $(P<0.25)$ between cows consuming corn silage-based diets and cows consuming sorghum silagebased diets ( 49.5 and $50.5 \mathrm{~kg} / \mathrm{d}$, respectively).

At least 2 plausible explanations exist for the difference in milk fat concentration when feeding corn silage- and sorghum silage-based diets. First, feeding corn silage-based diets might have resulted in milk fat depression as a result of the greater concentration of NFC in the diet (Table 1), the greater concentration of PUFA (Table 2), or a combination of both. Harvatine (2017) defined diet-induced milk fat depression as a decrease in milk fat yield of up to $50 \%$ with no change in milk yield or yield of other milk components. Under this definition, our results indicate that milk fat depression occurred. Also, high concentrations of C18:1 trans-10 in milk fat were associated with reductions in milk fat concentrations in several studies (Griinari et al., 1998; Baumgard et al., 2001; Shingfield et al., 2009). In this study, feeding corn silage-based diets resulted in greater secretions of $\mathrm{C} 18: 1$ trans-10 in milk fat and lower secretions of C4:0 and C6:0 (Table 5), which supports the possibility of a diet-induced milk fat depression. However, the secretion of de novo fatty acids did not differ between cows consuming different silage types $(P>0.83$; Table 5$)$. Therefore, based on the similar secretion of de novo fatty acids in milk (Urrutia and Harvatine, 2017), feeding corn silage-based diets did not result in a diet-induced milk fat depression. An alternative explanation for the difference in milk fat concentration when feeding corn silage- and sorghum silage-based diets is related to the mobilization of corporal fat reserves. Oleic acid (C18:1 cis-9) is considered a marker of corporal fat mobilization (Van Haelst et al., 2008; Nogalski et al., 2012). In this study, cows consum-

Table 4. Apparent total-tract nutrient digestibility of cows consuming corn silage-based diets or sorghum silage-based diets with and without the addition of xylanase (X and NX, respectively)

\begin{tabular}{|c|c|c|c|c|c|c|c|c|}
\hline Item, $\%$ & \multicolumn{2}{|c|}{ Corn silage } & \multicolumn{2}{|c|}{ Sorghum silage } & SEM & \multicolumn{3}{|c|}{$P$-value } \\
\hline $\mathrm{DM}$ & $78.5^{\mathrm{a}}$ & $76.1^{\mathrm{b}}$ & $73.8^{\mathrm{c}}$ & $73.6^{\mathrm{c}}$ & 0.85 & 0.01 & 0.02 & 0.05 \\
\hline $\mathrm{NDF}$ & $57.0^{\mathrm{a}}$ & $51.0^{\mathrm{b}}$ & $56.3^{\mathrm{a}}$ & $54.8^{\mathrm{a}}$ & 1.75 & 0.19 & 0.01 & 0.06 \\
\hline Starch & 99.3 & 99.1 & 96.3 & 96.8 & 0.62 & 0.01 & 0.39 & 0.12 \\
\hline
\end{tabular}

${ }^{a-c}$ Different superscripts within a row indicate a significant difference $(P<0.05)$. 
ing sorghum silage-based diets secreted more oleic acid in milk than cows consuming corn silage-based diets $(P$ $<0.01$; Table 5). It is possible that a high demand for energy in these cows in early lactation producing great amounts of milk was compensated for through the use of body reserves.

Cows consuming corn silage-based diets had greater DM (77.3 vs. $73.5 \% ; P<0.01)$ and CP (78.0 vs. $72.4 \%$; $P<0.01)$ digestibilities than cows consuming sorghum silage-based diets (Table 4). Based on the specificity of the xylanase and the lack of differences in performance, we find no biological reasons for the lower digestibilities observed when xylanase was supplemented in corn silage-based diets and not in sorghum silage-based diets.

Given that the sorghum silage had the BMR phenotype and the corn silage did not, it is noteworthy that cows consuming corn silage-based diets had a fairly similar NDF digestibility compared with cows consuming sorghum silage-based diets (54.0 and 55.6\%, respectively). Within plant species of similar genetic background, forages showing the BMR phenotype have lower lignin concentrations and higher fiber digestibilities than forages not showing the BMR phenotype (Oba and Allen, 1999, 2000). Therefore, within plant species, plants containing the BMR phenotype are expected to have greater fiber digestibility than plants without the
BMR phenotype (Oliver et al., 2004). In this study, in which different plant species were compared, the concentration of lignin was not lower and the NDF digestibility was not greater for sorghum silage-based diets relative to corn silage-based diets. Therefore, the data from this study and others (Oliver et al., 2004) show that forages with the BMR phenotype do not necessarily have higher fiber digestibilities than forages not showing the BMR phenotype.

Cows consuming corn silage-based diets showed a greater starch digestibility than cows consuming sorghum silage-based diets (99.2 vs. $96.5 \% ; P<0.01$; Table 4). The greater starch digestibility for corn silage-based diets than for sorghum silage-based diets has been previously reported (Oliver et al., 2004) and may be related to a greater disruption of the protein matrix surrounding the starch granules (Theurer, 1986) or to a poorer processing of the sorghum grains.

In this study, we aimed to evaluate different nutritional strategies to overcome the effects of drought stress scenarios, such as limited silage and hay availability and limited availability of good-quality hay. Contrary to our hypothesis, adding an EFE to diets containing poor-quality mixed grass had no effect on production performance of lactating dairy cows. Also, despite the poor quality of the grass hay, production

Table 5. Milk fatty acid secretion (g/d) of cows consuming corn silage-based diets or sorghum silage-based diets with and without the addition of xylanase ( $\mathrm{X}$ and NX, respectively)

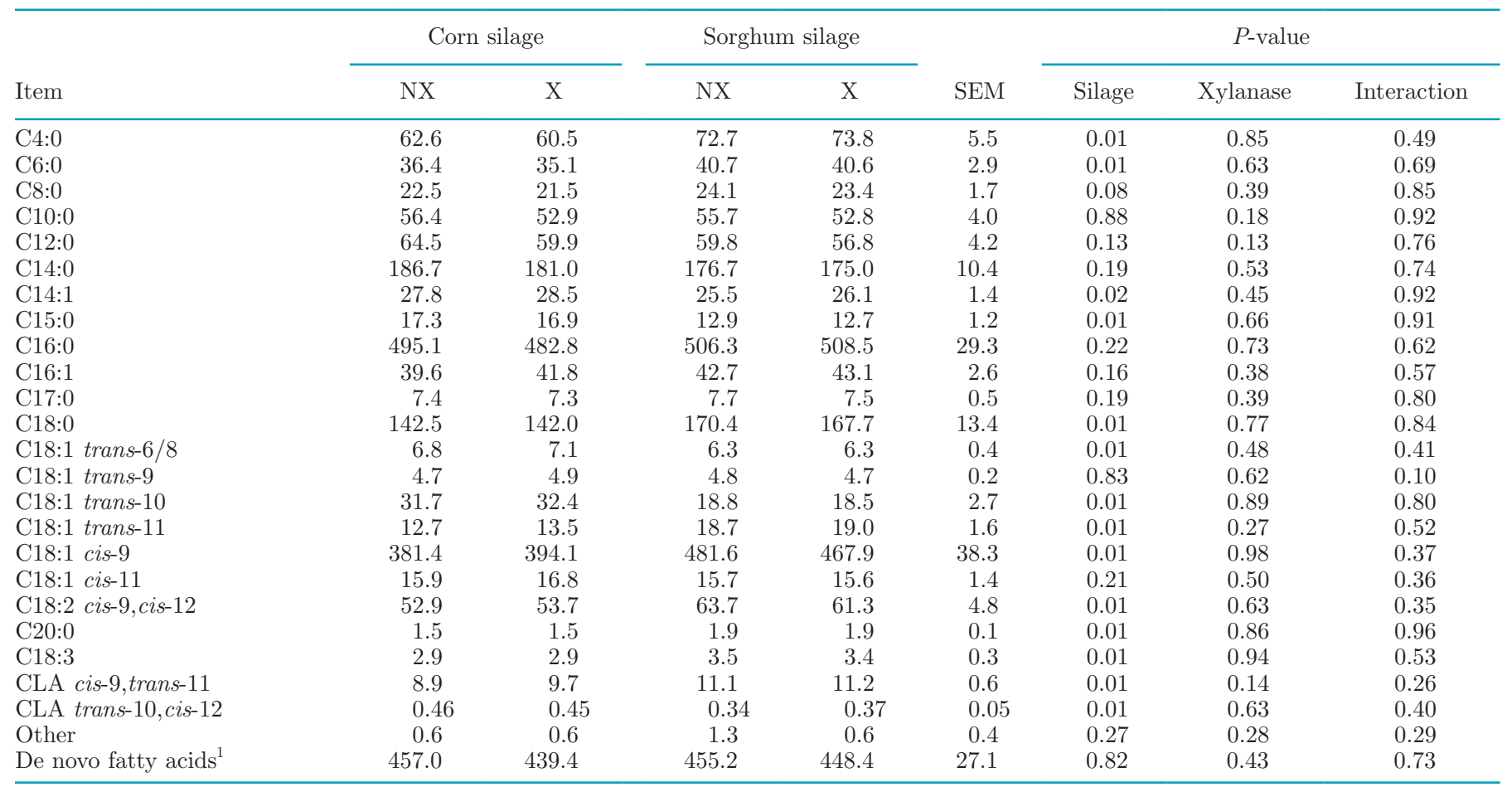

${ }^{1}$ De novo fatty acids are the sum of $\mathrm{C} 4: 0$ to $\mathrm{C} 14: 1$. 
performance was very satisfactory $(>48 \mathrm{~kg} / \mathrm{d})$ regardless of the type of silage used. This observation has major practical implications in the sense that milk production can still be sustained when supreme feed resources, such as alfalfa hay, are limiting. Regarding silage type, cows consuming corn silage-based diets produced more milk, but cows consuming sorghum silage-based diets produced more milk fat, therefore resulting in similar $3.5 \%$ FCM yields $(P<0.25$; Table 3$)$. This observation has major implications in regions where milk prices are determined primarily by the fat concentration in milk.

\section{CONCLUSIONS}

In conclusion, xylanase supplementation did not improve production performance when high-producing dairy cows were fed low-forage diets containing corn or sorghum silages and poor-quality grass hay. In addition, production performance can be sustained by feeding sorghum silage in replacement of corn silage. This strategy can be very beneficial to dairy farmers, especially in scenarios of postdrought stress, when forage stocks decrease and prices of forages and grains increase.

\section{ACKNOWLEDGMENTS}

We are grateful to Chrissy Teets for her assistance in the laboratory and to students Emily Richardson (animal and poultry sciences), Sarah Thomas, and Becky Wilkins (dairy science) for their assistance with feeding cows and collecting, processing, and analyzing samples (Virginia Tech, Blacksburg). This project was funded partially by DSM Nutritional Products (Parsippany, NJ), USDA (Washington, DC) National Institute of Food and Agriculture (NIFA) Hatch Project VA-160025, and USDA NIFA Multistate Project VA136291 (NC-2042, Management Systems to Improve the Economic and Environmental Sustainability of Dairy Enterprises).

\section{REFERENCES}

Åman, P. 1993. Composition and structure of cell wall polysaccharides in forages. Pages 183-199 in Forage Cell Wall Structure and Digestibility. H. G. Jung, D. R. Buxton, R. D. Hatfield, and J. Ralph, ed. American Society of Agronomy, Crop Science Society of America, and Soil Science Society of America, Madison, WI.

AOAC International. 2016. Official Methods of Analysis of AOAC International. 20th ed. AOAC International, Rockville, MD.

Arriola, K. G., S. C. Kim, C. R. Staples, and A. T. Adesogan. 2011. Effect of fibrolytic enzyme application to low- and high-concentrate diets on the performance of lactating dairy cattle. J. Dairy Sci. 94:832-841.

Arriola, K. G., A. S. Oliveira, Z. X. Ma, I. J. Lean, M. C. Giurcanu, and A. T. Adesogan. 2017. A meta-analysis on the effect of dietary application of exogenous fibrolytic enzymes on the performance of dairy cows. J. Dairy Sci. 100:4513-4527.

Baumgard, L. H., J. K. Sangster, and D. E. Bauman. 2001. Milk fat synthesis in dairy cows is progressively reduced by increasing supplemental amounts of trans-10, cis-12 conjugated linoleic acid (CLA). J. Nutr. 131:1764-1769.

Bernard, J. K., and S. Tao. 2015. Short communication: Production response of lactating dairy cows to brachytic forage sorghum silage compared with corn silage from first or second harvest. J. Dairy Sci. 98:8994-9000.

Brown, M. E., and C. C. Funk. 2008. Food security under climate change. Science 319:580-581.

Cattani, M., N. Guzzo, R. Mantovani, and L. Bailoni. 2017. Effects of total replacement of corn silage with sorghum silage on milk yield, composition, and quality. J. Anim. Sci. Biotechnol. 8:15.

Chouinard, P. Y., L. Corneau, A. Saebo, and D. E. Bauman. 1999 Milk yield and composition during abomasal infusion of conjugated linoleic acids in dairy cows. J. Dairy Sci. 82:2737-2745.

Collins, T., C. Gerday, and G. Feller. 2005. Xylanases, xylanase families and extremophilic xylanases. FEMS Microbiol. Rev. 29:3-23.

Ferreira, G., and D. R. Mertens. 2007. Measuring detergent fibre and insoluble protein in corn silage using crucibles or filter bags. Anim. Feed Sci. Technol. 133:335-340.

Grant, R. J., S. G. Haddad, K. J. Moore, and J. F. Pedersen. 1995. Brown midrib sorghum silage for midlactation dairy cows. J. Dairy Sci. 78:1970-1980.

Griinari, J. M., D. A. Dwyer, M. A. McGuire, D. E. Bauman, D. L. Palmquist, and K. V. Nurmela. 1998. Trans-octadecenoic acids and milk fat depression in lactating dairy cows. J. Dairy Sci. $81: 1251-1261$

Hackmann, T. J., J. D. Sampson, and J. N. Spain. 2008. Comparing relative feed value with degradation parameters of grass and legume forages. J. Anim. Sci. 86:2344-2356.

Hall, M. B. 2009. Determination of starch, including maltooligosaccharides, in animal feeds: Comparison of methods and a method recommended for AOAC collaborative study. J. AOAC Int. 92:42-49.

Harper, M. T., A. Melgar, J. Oh, K. Nedelkov, G. Sanchez, G. W. Roth, and A. N. Hristov. 2018. Inclusion of brown midrib dwarf pearl millet silage in the diet of lactating dairy cows. J. Dairy Sci. 101:5006-5019.

Harvatine, K. J. 2017. Lipid and fat nutrition. Pages 655-666 in Large Dairy Herd Management. 3rd ed. D. K. Beede, ed. American Dairy Science Association, Champaign, IL.

Hasan, S. A., S. H. Rabei, R. M. Nada, and G. M. Abogadallah. 2017. Water use efficiency in the drought-stressed sorghum and maize in relation to expression of aquaporin genes. Biol. Plant. 61:127-137.

Mertens, D. R. 1997. Creating a system for meeting the fiber requirements of dairy cows. J. Dairy Sci. 80:1463-1481.

Nogalski, Z., M. Wroński, M. Sobczuk-Szul, M. Mochol, and P. Pogorzelska. 2012. The effect of body energy reserve mobilization on the fatty acid profile of milk in high-yielding cows. Asian-australas. J. Anim. Sci. 25:1712-1720.

NRC. 2001. Nutrient Requirements of Dairy Cattle. 7th rev. ed. National Academies Press, Washington, DC.

Oba, M., and M. S. Allen. 1999. Effects of brown midrib 3 mutation in corn silage on dry matter intake and productivity of high yielding dairy cows. J. Dairy Sci. 82:135-142.

Oba, M., and M. S. Allen. 2000. Effects of brown midrib 3 mutation in corn silage on productivity of dairy cows fed two concentrations of dietary neutral detergent fiber: 3. Digestibility and microbial efficiency. J. Dairy Sci. 83:1350-1358.

Oliver, A. L., R. J. Grant, J. F. Pedersen, and J. O'Rear. 2004. Comparison of brown midrib- 6 and -18 forage sorghum with conventional sorghum and corn silage in diets of lactating dairy cows. J. Dairy Sci. 87:637-644.

Roby, M. C., M. G. Salas Fernandez, E. A. Heaton, F. E. Miguez, and A. VanLoocke. 2017. Biomass sorghum and maize have similar water-use-efficiency under non-drought conditions in the rain-fed Midwest U.S. Agric. For. Meteorol. 247:434-444. 
Rohweder, D. A., R. F. Barnes, and N. Jorgensen. 1978. Proposed hay grading standards based on laboratory analyses for evaluating quality. J. Anim. Sci. 47:747-759.

Rychen, G., G. Aquilina, G. Azimonti, V. Bampidis, M. L. Bastos, G. Bories, A. Chesson, P. S. Cocconcelli, G. Flachowsky, J. Gropp, B. Kolar, M. Kouba, M. López-Alonso, S. López Puente, A. Mantovani, B. Mayo, F. Ramos, M. Saarela, R. E. Villa, R. J. Wallace, P. Wester, P. Brantom, N. A. Dierick, and M. Anguita. 2017. Safety and efficacy of RONOZYME ${ }^{\circledR}$ WX (endo-1,4- $\beta$-xylanase) as a feed additive for laying hens. EFSA J. 15:e05020.

Sattler, S. E., D. L. Funnell-Harris, and J. F. Pedersen. 2010. Brown midrib mutations and their importance to the utilization of maize, sorghum, and pearl millet lignocellulosic tissues. Plant Sci. $178: 229-238$

Shingfield, K. J., A. Saebo, P. C. Saebo, V. Toivonen, and J. M Griinari. 2009. Effect of abomasal infusions of a mixture of octadecenoic acids on milk fat synthesis in lactating cows. J. Dairy Sci. 92:4317-4329.
Theurer, C. B. 1986. Grain processing effects on starch utilization by ruminants. J. Anim. Sci. 63:1649-1662.

Urrutia, N. L., and K. J. Harvatine. 2017. Acetate dose-dependently stimulates milk fat synthesis in lactating dairy cows. J. Nutr. 147:763-769.

USDA. 2013. Crop Production 2012. National Agricultural Statistics Service, Washington, DC.

Van Haelst, Y. N., A. Beeckman, A. T. Van Knegsel, and V. Fievez. 2008. Short communication: Elevated concentrations of oleic acid and long-chain fatty acids in milk fat of multiparous subclinical ketotic cows. J. Dairy Sci. 91:4683-4686.

Wang, Y., and T. A. McAllister. 2002. Rumen microbes, enzymes and feed digestion-A review. Asian-australas. J. Anim. Sci. 15:16591676.

Yang, Y., G. Ferreira, C. L. Teets, B. A. Corl, W. E. Thomason, and C. A. Griffey. 2017. Effects of feeding hull-less barley on production performance, milk fatty acid composition, and nutrient digestibility of lactating dairy cows. J. Dairy Sci. 100:3576-3583. 